\title{
The Historical Role of Tibetan Buddhism in the Inheritance of Ethnic Cultures
}

\author{
Liying Ren \\ Chifeng University \\ Chifeng, Inner Mongolia 024000
}

\begin{abstract}
Religion, as the longest-lasting and most widely distributed human cultural phenomenon, has a deep and profound influence on human life and the degree of it is selfevident. Religion can be found everywhere in spiritual activities, belief patterns, mental states, behaviors, ethics and customs of human. We should adhere to make the past serve the present, weed through the old to bring forth the new; and we should treat religions discriminatively, inherit the essence of them, discard those that are contrary to the times and requirements of social progress, and abandon the heterodoxies, outdated conventions and bad customs that are inconsis tent with the laws and current policies of the nation; and we should combine the ancient ideas of Tibetan Buddhism with new practices in the new era. In this way, we can achieve the creative transformation and innovative development of the Tibetan Buddhism culture, rejuvenating the vitality of Tibetan Buddhism in today's society.
\end{abstract}

Keywords—ethnic cultures; Tibetan Buddhism; historical role

Culture is an important factor in social life, possessing social values that satisfy people's spiritual needs. Huang Xiujian expressed some opinions in his master's paper, namely "Historical materialism puts forward that religion and culture of human were formed simultaneously at first; the earliest thoughts of mankind were expressed in the form of religion; the primitive culture appeared first in primitive religion and we can say that primitive religion is the origin sign of human culture; in the initial stage of human beings, people began to pay attention to the surrounding world, giving birth to a primitive complex of intertwining prayers, desires, horror and awe of life and death gradually and the ultimate demand of human beings is the common source of the birth of religion and culture; the primitive religion and philosophy were originally merged together; religion is the world view and outlook on life of ancient human beings, and it is the embryonic form of philosophy and creates conditions for the birth of philosophy" [1]. Religion, as the longest-lasting and most widely distributed human cultural phenomenon, has a deep and profound influence on human life and the degree of it is self-evident. Religion can be found everywhere in spiritual activities, belief patterns, mental states, behaviors, ethics and customs of human. As religion is rooted in humanity, it will absolutely play a unique role in any era and any society of human civilization.

Engels, a great philosopher and revolutionist in Germany, believes that "religion", as the "centripetal force" and "cohesion" in the relevant society, will play a role in social integration, namely "internal unity." The feudal separatism in the Middle Ages of Europe made it difficult to realize or embody the "unification of Europe", but the "unification" was reflected to a considerable extent at the spiritual level, that is, at the religious level. The "unification of faith" and "consensus of the spirit" and the building of the 'common' "spiritual homeland" should be considered as an improvement under the historical conditions of the time--a positive spirit of enterprise of the relevant society. Religion expresses the ideals and visions of the "unification" of human society with its representative value system, ideology, national spirit and cultural symbols. However, the "unification" in this sense of faith is not just the unification of abstractness. It provides a huge spiritual support for the co-building of the relevant society and it is a potential driving force for its "cultural unity" and "social unity" [2].

\section{IMPORTANT CARRIERS FOR ETHNIC CULTURAL EXCHANGES AND EMERGENCE}

Since the Yuan Dynasty, Tibetan Buddhism has been spreading in the Mongolian region for more than 700 years. It has been more than 400 years since the end of the Wanli reign period (appeared during the Ming Dynasty of China). Tibetan Buddhism has become a common historical memory of Mongols. The long-standing inertia of historical memory and the magnetic field of national emotions are tied to the temples of Tibetan Buddhism.

In the Qing Dynasty, the spread of Tibetan Buddhism in the Mongolian areas, the northeastern regions, Beijing, Hebei and Shanxi provinces further promoted the national unification of the Qing Dynasty. Hu Richa and other people proposed some ideas in their book, namely "The seal of the Fifth Dalai Lama connected the beliefs of the three peoples of Tibet, Mongolia and Manchu, becoming the most powerful religious force in the history of North Asia'"[3]. The policies and measures of the use, support and encouragement of Tibetan Buddhism adopted by the Qing court not only brought closer relations between the Qing court and the Mongolian-Tibetan Buddhist monastic groups, but also accelerated the historical process of the unification of multi-ethnic states in the early Qing Dynasty. The cultural exchanges between Manchu\& Mongolian, Mongolian\& Han people and Mongolian \&Tibetans also led more Manchu and Han people to enter the ranks of Tibetan Buddhist believers, hence making them an important part of the local society. Peoples began to identify with mergence. Believers traction function of Buddhism contributes to the socialization of individuals, thereby increasing group 
interactions in the process of socialization and merging different individuals and groups into a highly unified and coordinated whole in specific beliefs and ceremonials to enhance its internal identity gradually.

The large and small Lama Temple in the Chifeng area of Inner Mongolia is a materialized carrier of the long history and culture and it is indeed a cultural relic with numerous stories, buildings, temples and pavilions. It blends the artistic styles of Han, Mongolian and Tibetan, and many Buddha statues, murals and thangkas, the unsophisticated and dignified Buddhist activities as well as the fresh and elegant Vatican chanting all inherit the essence of Chinese traditional culture. Whether believers or tourists, their perceptual knowledge of traditional culture can be increased and the deep and profound connotation of traditional culture can be appreciated when walking into monasteries. The Mongolian translation of the classic Buddhist scriptures promoted the development of translation and philology. The "medicine" in the temple promoted the development of the Mongolian medical cause. Most of the temples became the research, development and communication center of Mongolian culture. The inheritance of a lot of subject literatures of history, medicine, astronomy, calendar, logic, religion, philology and art in the history of Mongolian as well as relevant knowledge cannot be separated from religion[4]. This should be the greatest contribution of Tibetan Buddhism to Mongolian culture, and this contribution will continue.

\section{The national CUltural CONSENSUS PROMOTES THE INTEGRATION OF THE NATION}

The Tibetan Buddhism belief is based on the close connection between the Mongolian and Tibetan cultures. The long-term relationship between the Mongolian and Tibetan people has gone from the cultural field to the political field, and Tang Jisi wrote "finally brought the Mongolian and Tibetan cultures into the unified cultural category of the Chinese nation” [5] in his book.

The "impermanence" of religion is the change of philosophy. For example, the aging and death of the human body begins from the time of pregnancy, not begins at the age of sixty or seventy. Life and death are carried out simultaneously. From the perspective of life, we will gradually experience stages of young, middle-aged and old from birth, and then will finally die; from the perspective of death, every minute after birth lapses away in life, so we only remain 99 years when we are 1 year old if the life span of person is 100 . From the perspective of individual life, a person today is not who he is yesterday, and a person tomorrow is not who he is today. Everything is changing, including people's body and thoughts. The ancient Greek philosopher Heraclitus once said that "people cannot cross the same river twice." In fact, "Everything is flowing, and everything is always new." When you cross the river, the water has already flown away; when you return, the river is no longer the original one. The classic Buddhist story interprets the rarity and preciousness of life with vivid language and plain truth. There is an example named 'Perforation of a blind turtle "--there is a blind turtle swimming in the boundless sea. When it is a hundred years old, it will breathe over the surface of sea. A plate with holes is floating on the sea and the new cycle of life is born when the head of the blind turtle is put into the wood. Other example is "Riding wild donkeys"--there is a blind person named Zhu Gu. Some day when he walks on the road, he falls off the soil cliff. At this time, there is a wild donkey running down the cliff and Zhu Gu just ride on the wild donkey. The chance to get a life is as rare as a blind person accidentally falls on the back of a wild donkey. Another example is "Needle tips through beans"- we insert a small sewing needle on the ground and then sprinkle the mustard on the needle and will find the probability of the mustard staying on the needle tip is the odds to gain a life. In the extension process of history and culture of human society, almost all possible contradictions and conflicts, human beings, people and Tao, human and nature and all kinds of natural and man-made disasters in life are the growing sufferings experienced by all ethnic groups. "Life and death" and "being and not being" are core issues that people of all ethnic groups have been discussing all the time of history. Religion, through the depreciation of secular values, the respect for the interests of all sentient beings, the reverence for karma, and the yearning for the beautiful afterlife, alleviates people's persistent pursuit of fame and fortune and fills the blankness in people's minds, adjusting the imbalance in the hearts of people to a relatively balanced mental state. Religion plays a positive role in psychological debugging. In different historical periods, religion has enabled different ethnic groups to acquire a unified national and cultural identity to a certain extent, and to form a consensus on the excellent traditional culture of the Chinese nation, hence promoting mergence of the Chinese nation.

\section{The VAlue AND CUltural SYSTEM OF "TAOISM" AND " LEARNING"}

Tibetan Buddhism places special emphasis on obedience. With the help of religious organizations with ethnic characteristics, it uses disciplinary, public opinion, beliefs, art, etiquette, life values and ethics to stress that the punishment will be given generation after generation on those who isn't obtain desire for goodness . Mankind, in the fear of the Buddha, will succumb to the supernatural power of religious presupposition. Taking "prohibit all evils, advocate good deeds, and adjust temperament" as the principle of practice, religion proposes all-round restraint on human spirit and behavior and supervises people outside social law and morality, achieving a soft control out of kindness. As a long-standing social and cultural phenomenon, the teachings and doctrines of religion are based on the spirit of Bodhisattva and they uphold the compassion, demanding believers be compassionate and people be sympathetic to each other. The emphasis of compassion is the indispensable virtue of becoming a Buddha and it teaches the world to be good and to do good deeds, which advances social charity and public welfare activities to a certain extent and promotes more harmonious cultural exchanges in interpersonal communication in the intangible. The most basic "five precepts" that are adhered to in personal practice, namely "not killing, not taking, not being sinister, not swearing, not drinking", are beneficial to people's physical and mental health and contribute to family and social harmony. From "karma" to "reincarnation ", we advise believers to support their parents, respect the elders, talk gently, be willing to share, and the husband and wife are loving and respectful. From "merciful 
and great compassion" and "responding to every plea" of the Goddess of Mercy to the widely known Amitabha, it advises people to achieve spiritual perfection through social life practice. The teachings and doctrines of Tibetan Buddhism analyze and answer these questions in a way that meets the needs of social culture and provides rich spiritual resources for the socialist society's interpersonal communication and social harmonious development. For two thousand years, many religious ideas have been internalized in the hearts of the world in various forms, and they are often revealed intentionally or unconsciously through words and deeds. From China's backcountry, the hustle and bustle of the city to the world's skyscrapers and science and technology institutions, religion is playing the role of cultural inheritance in this internalized way. Religion admonishes believers not to try to seek external eternality to avoid "law enforcement" or to regard the self as too important to prevent "obsession"; we should try to achieve a clear and static "no self" and "having self" through the complete transformation of the heart. Religion emphasizes selfimprovement, reminding people in the world not to ignore the promotion of spiritual realm and should promote communication with each other in good faith and focus on the improvement of self and spiritual world. It advocates sincere and simple interpersonal relationships, and simple and healthy lifestyle. It cares for life, pursuing interaction with equality between people and nature. It plays an important role in the harmonious relationship between people, people and society, and man and nature. It has important reference significance for building socialist spiritual civilization and building $a$ harmonious society.

Of course, Tibetan Buddhism also has certain negative effects. For example, it dispels the spirit of struggle and the complex and mysterious religious activities and rituals consume the limited funds, and some feudal superstitions with religious cloaks appear, which are worthy of high attention and strict precautions. We should strengthen the protection of the cultural inheritance of Tibetan Buddhism and promote the excavation, arrangement, publication and utilization of Tibetan Buddhist classics. The Tibetan Buddhism community must locate and clarify the direction and actively explore effective measures to make it a window to spread excellent traditional culture, a pure land for promoting socialist core values, and a holy place to purify people's hearts. Based on serving the society and benefiting mankind, it will spread the culture with characteristics of Tibetan Buddhism to the society, such as medicine, painting and architecture. We must guide the religious community to advocate classics, learning classics and preaching classics. Tibetan Buddhism has important realistic significance and practical value in the contemporary society, such as water conservation, simple and environmentally friendly lifestyle, selflessness, respect for words, and charitable thoughts that mourn the sentient beings. We should handle the relationship between inheritance and innovation well and make innovative interpretations on traditional doctrines according to the characteristics and requirements of the times, adding new vitality to Tibetan Buddhist classics.

\section{CONCLUSION}

Religion is an important part of human traditional culture, which affects people's ideology, customs and so on. In the Qing Dynasty, those religious leaders swam between the upper ruling classes, proclaiming their religious ideas, adhering to the rights of the rulers and integrating social resources to win the supreme glory. At the same time, they carried out a series of charities, like disease curing, medicine and porridge providing in the lower level. It has had a tremendous impact on the fields of politics, economy, philosophy, literature, art, astronomy, calendar, law, science and technology, medicine, architecture and so on and it is a sacred, mysterious and awe-inspiring place in the hearts of ordinary people. To this end, we should adhere to make the past serve the present, weed through the old to bring forth the new; and we should treat religions discriminatively, inherit the essence of them, discard those that are contrary to the times and requirements of social progress, and abandon the heterodoxies, outdated conventions and bad customs that are inconsistent with the laws and current policies of the nation; and we should combine the ancient ideas of Tibetan Buddhism with new practices in the new era. In this way, we can achieve the creative transformation and innovative development of the Tibetan Buddhism culture, rejuvenating the vitality of Tibetan Buddhism in today's society. We should carry forward patriotism, traditional virtues and harmonious thoughts of Tibetan Buddhism as well as the excellent traditional culture. We must keep up with the pace of the times, stand on the tradition, be inclusive, pioneering and enterprising, and truly shoulder the historical responsibility of developing the outstanding Chinese traditional culture, making its due contribution to the Chinese dream of the great rejuvenation of the Chinese nation.

\section{REFERENCES}

[1] Huang Jianxiu. Research on the Positive Role of Religion in the Construction of a Harmonious Society. Master's Paper of the Minzu University of China. 2008.

[2] Zhuo Xinping. Religion and Contemporary China under Globalization. Social Sciences Academic Press. 2008, page178.

[3] Hu Richa, Qiao Ji, Wu Yun, etc. The study of the spread of Tibetan Buddhism in Mongolia. National Publishing House. 2012.

[4] Tang Jisi. Investigation and Research on Mongolian Buddhist Culture. Liaoning Nationalities Publishing House. 2010.

[5] Tang Jisi. Investigation and Research on Mongolian Buddhist Culture. Liaoning Nationalities Publishing House. 2010, page17.

[6] Meng Guangyao. Northeast Asian Studies: Research on Northern Ethnic History. Zhongzhou Ancient Books Publishing House. 1994.

[7] Tang Jisi. Investigation and Research on Mongolian Buddhism Culture. Liaoning Nationalities Publishing House. 2010.

[8] Su Luge. Mongolian Religious History. Liaoning Nationalities Publishing House. 2006.

[9] De Lege. History of Lamaism in Inner Mongolia. Inner Mongolia People's Publishing House. 1998.

[10] Qiao Ji. History of Mongolian Buddhism. Inner Mongolia People's Publishing House. 2008. 